\title{
Tracing the History and Theories of Architecture: Documenting and Analyzing the Most Important Historical Periods that Influenced the Development of Architecture: (232 A.D -1918 A.D)
}

\author{
Zaid.M.Al-Zrigat* \\ Architecture Department, Hashemite University, Jordan \\ *Corresponding author: Zaid.M.Al-Zrigat, Architecture Department, Hashemite University, Jordan
}

\begin{abstract}
The context of the research aims to explain and simplify the stages of the development of architecture in pre and post history. By focusing on the integrative relationship between theories of architecture and design across different eras, by making comparisons in the architectural style and innovative structural elements of each historical era (Christianity, Byzantine, Sassanid, Roman, Islamic, Ottoman).The subject of the research focuses on mentioning the most important historical architectural examples that exist to measure the appropriateness of using and reflecting the concept of classical architecture on our lives today, and developing strategic skills to bridge the deficiency in human needs at any time and place. And highlighting the importance of environmental factors and their impact on architectural eras.
\end{abstract}

Keywords: Theories architecture; History architecture; Christianity; Byzantine; Sassanid; Roman; Islamic; Ottoman

\section{Introduction}

The concept of architecture is associated with historical events, design, and construction of buildings and archaeological structures. It is a multidisciplinary field based on mathematics, science, art, technology, social science, politics, history, and philosophy. It is limited to the level of social dimensionsJackie Craven [1].The history of architecture helps to address aesthetic (Delight), structural (Firmness) and functional (Commodity) considerations, in addition to studying what has been built in the past chronologically (arranged according to order or sequence). In an analytical framework that reflects social, economic, and technological systemsOrigins of architecture [2].The idea of creating and inventing architectural theories depends on restoring the real physical reality of the things built (reconstruction), through archeology and the interpretation of the purpose of each structural element that appeared in a particular period and the reason for using each period building materials and infrastructure that distinguishes them from others, and how the impact of religion on The dominant architectural stylePatina Lee [3].

\section{Literature Review}

\section{Christian Architecture (232-324 A.D)}

The concept of architecture history began to coincide with the architecture of the Roman Catholic Church, as this architecture witnessed an important political, religious, social, and historical aspect. As the historical aspect took an important role in the prosperity and growth of Christian architecture in Italy, but it did not create new architectural styles or theories in its timeGlasgow School of Art [4].Christian architecture spread throughout the Roman Empire, but at the time the importance of the churches was not exploited or given value, they were using houses and landscapes of worship instead. The dominant architectural style of the churches was the longitudinal church or a mausoleumDr. Allen Farber [5](Figure 1).

The shape of church buildings later became similar to the Roman cathedral in terms of symbolic connotations, speed of construction, 
low cost, and lack of required structural adjustments, as they were characterized by an abundance of columns and decoration that reflect the religious and spiritual meanings of the Christian religion. Dr. Allen Farber [5](Figure 2).

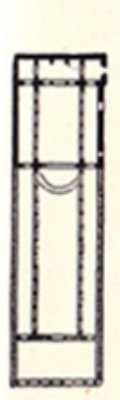

A

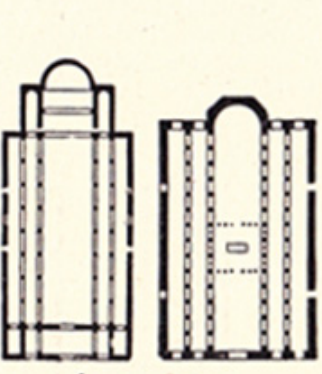

C

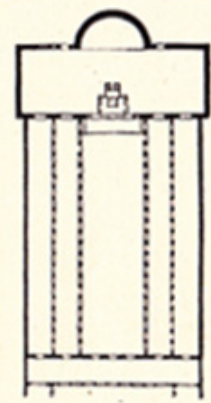

D

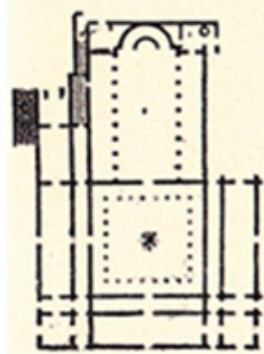

E

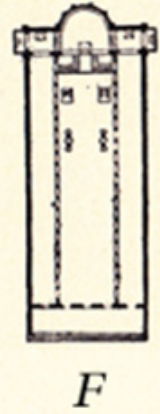

F

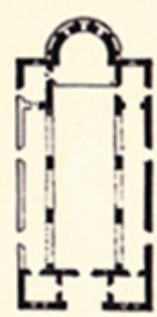

G

Figure 1: (A) St. Lorenzo, Rome; (B) Basilica in Suweda, Syria; (C) Basilica Ursiana, Ravenna; (D) St. Paul's, Rome; (E) Xenodochium of Pammachius, Porto; (F) St. Maria Maggiore, Rome; (G) Basilica in Kalb-Luseh, Syria.
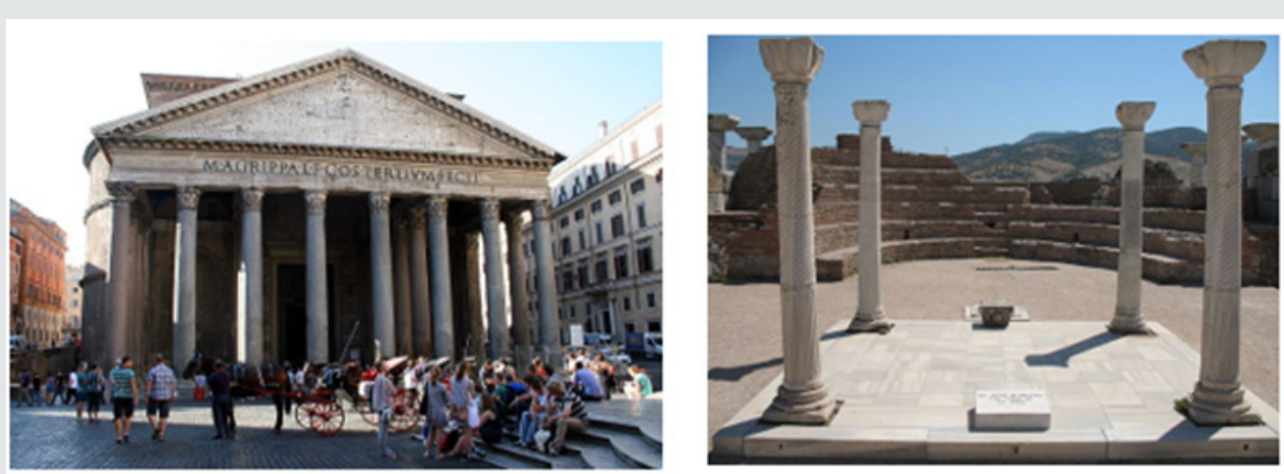

Figure 2: (A) Pantheon, completed 126 C.E., Rome; (B) The Tomb of St. John the Apostle from the Basilica of St. John, 6th century, Ephesus, near modern day Selçuk, Turkey.

Then, in the sixteenth century, churches developed under the concept of the basilica, such as Basilica: S. Peter's Rome, which consists of main parts that distinguish it: atrium; Narthex, Or the porch; Long nave (central hall); Transept hall crossing the nave; the altar; the Mausoleums and Baptistery, which later become design elements for every church designerThe Editors of Encyclopaedia Britannica [6](Figure 3).
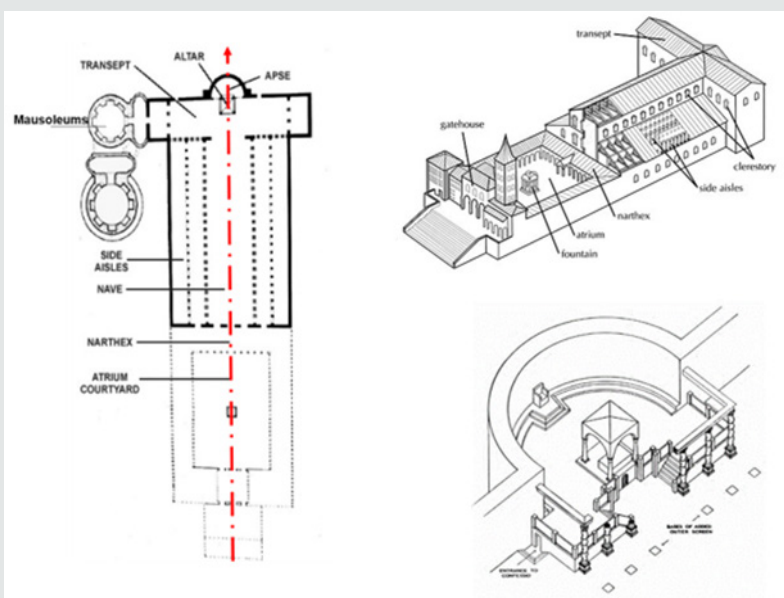

Figure 3: PlanBasilica: S. Peter's Rome; Perspective and 3D views. 
Early Christian art not only used Roman forms, but it also used Roman styles. Early Christian Architecture: basilical church developed from the Roman secular basilica and early houses courts; centralized type from Roman tombsAmy Raffel [7].

\section{Byzantine Architecture (324-900 A.D)}

The wars of conquest were dominant in the year 476 A.D, and after that, the Roman Empire was divided into East and West, where the Western Empire preserved the Roman culture and its architectural style and became called the „Byzantine Empire”. Justinian I was the greatest of the conquerors and builders. His enduring architectural achievement was Hagia SophiaWilliam R
Caraher [8].Stone is the main building material that was used in the construction and restoration of antique buildings and churches and was brought in from eastern Constantinople. Buildings were characterized by flat ceilings with domes, small, narrow and high openings, continuous walls, the use of a sophisticated program of the interior structure, lighting, and decoration to create wonderful interiorsROGER STEPHEN SHARP [9](Figure 4).

Byzantine architecture developed to focus on the use of simple, twisted, and pendentive (hanging) domes of various domes that provided a unique way to adjust the circular shape of the dome ceiling to a square or polygonal scheme and to use abundant motifs such as mosaicMark Cartwright [10](Figure 5).
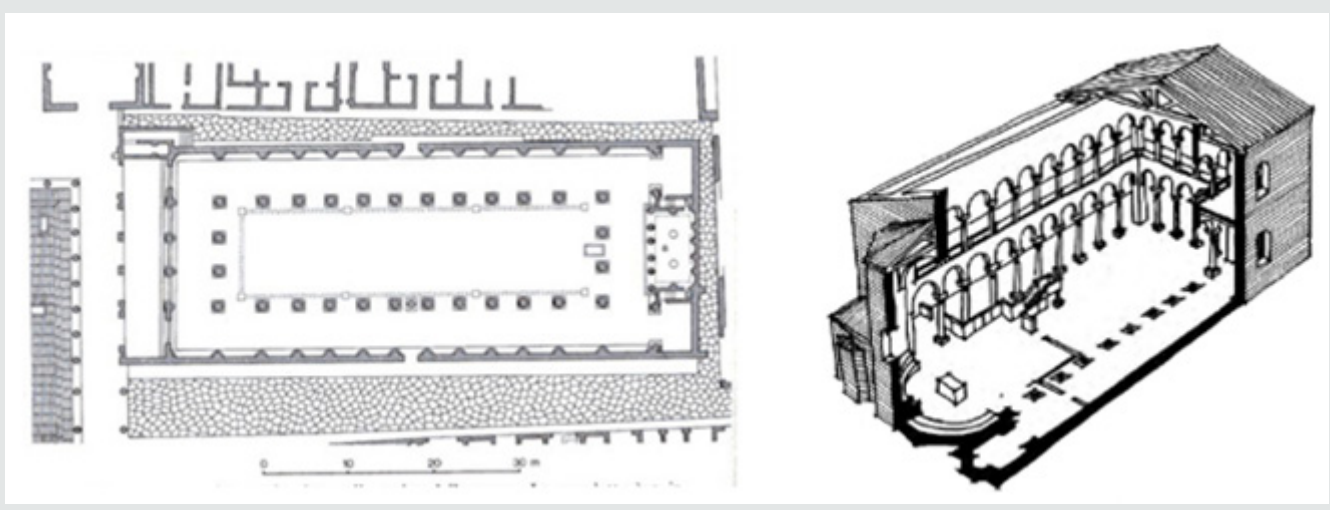

Figure 4: Plan; The Basilica at Pompeii; Perspective and 3D views.
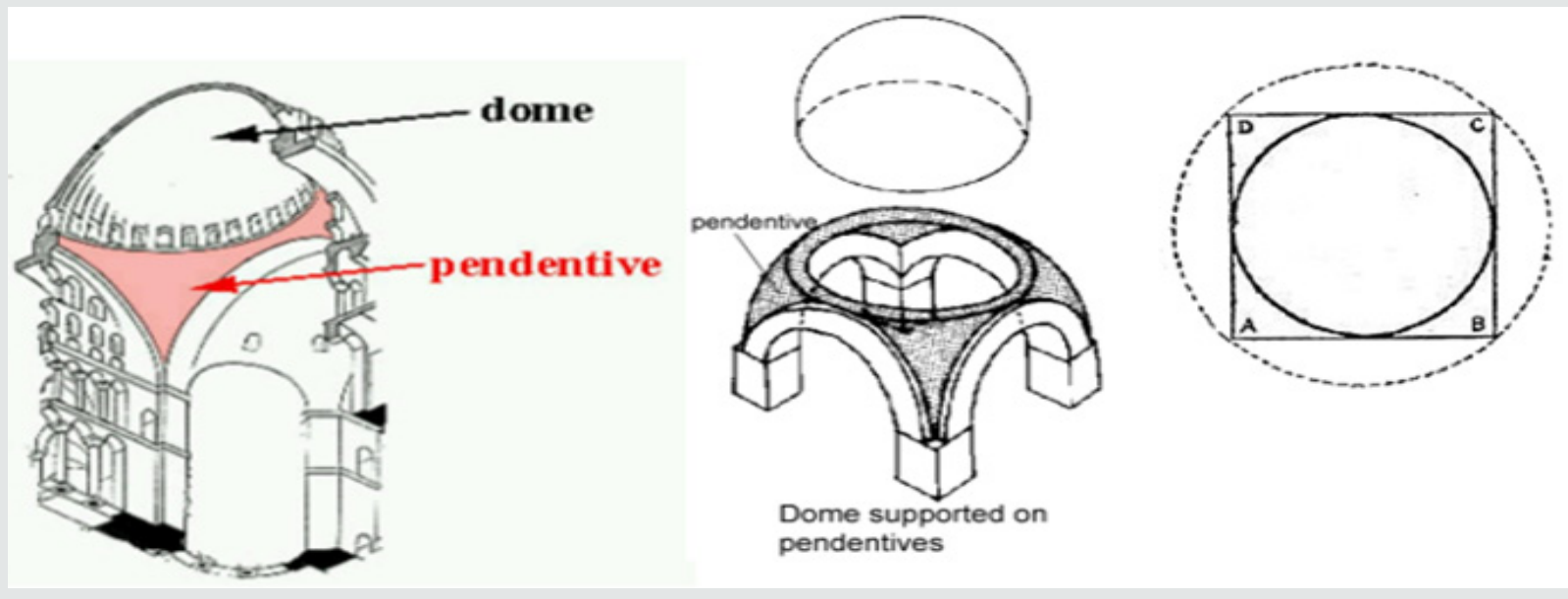

Figure 5: Plan; pendentivedome;Byzantine architecture.

\section{A comparison between the horizontal projection of the Byzantine Church and the Christian Church}

\begin{tabular}{|c|c|c|}
\hline \multirow{2}{*}{ Components } & Byzantine Church & Christian Church \\
\cline { 2 - 3 } Visual impression & $\begin{array}{c}\text { The Byzantine church gives a vertical impression because of the } \\
\text { grouping of subsidiary domes around a central dome. The eye is } \\
\text { gradually drawn upwards towards the central culminating dome }\end{array}$ & $\begin{array}{c}\text { The Early Christian church gives a horizontal impression, } \\
\text { because of the vista of columns, entablatures, and a simple } \\
\text { timber roof. The eye is led along these horizontal lines to } \\
\text { the apsidal sanctuary which is the important feature. }\end{array}$ \\
\hline
\end{tabular}

Citation: ZaidM Al-Zrigat. Tracing the History and Theories of Architecture: Documenting and Analyzing the Most Important Historical 
The shape of the openings in the Byzantine domes is characterized as circular or straight in the form of a horseshoe, small openings that allow continuous walls without interruption under the domes. Arcades; the semicircular arches on monolithic columns with convex crowns largely used in churches, especially to support galleries. Small and grouped, sometimes arranged in layers within a semicircular arc beneath the domeMark J. Johnson [11].
The pillars were widely used as a structural and aesthetic component as they consisted of one piece of colored marble. The columns were taken from ancient Roman buildings such as monolithic shafts, capitals, Roman Ionian, Corinth, a compound that combines the sizes of the vertical Ionic system with the Corinthian rank acanthus leavesMark Cartwright [10](Figure 6).
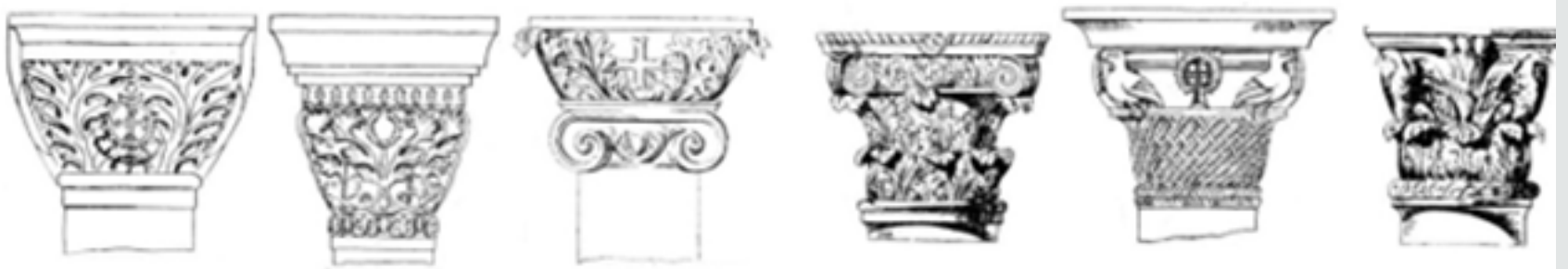

Figure 6: Types of columns in the Byzantine period.

The Byzantine decoration is characterized by being painted on marble with carefully arranged veins to form Vaults patterns. The colored decoration covered the walls, floors, ceilings, domes, and columns, where the golden color was the most popular and used. The effect of the wonderful oriental sunlight that wore them with a piece of glowing color gave a great variety of facades. Inside, it was suitable for marble, mosaic, and plasterboard decorationJ. Arnott Hamilton [12].
One of the most famous architectural examples is Byzantine Church-San Vitale, Ravenna-540 A.D. It was the first model ofHagia Sophia that was built 10 years later, as it features an octagonal template and exterior walls surrounded by a mobile base from the ground level and exhibited above it, and it has an apse that extends from the central core is to one of the eight sides of the external appraiserAgnellus [13](Figure 7).
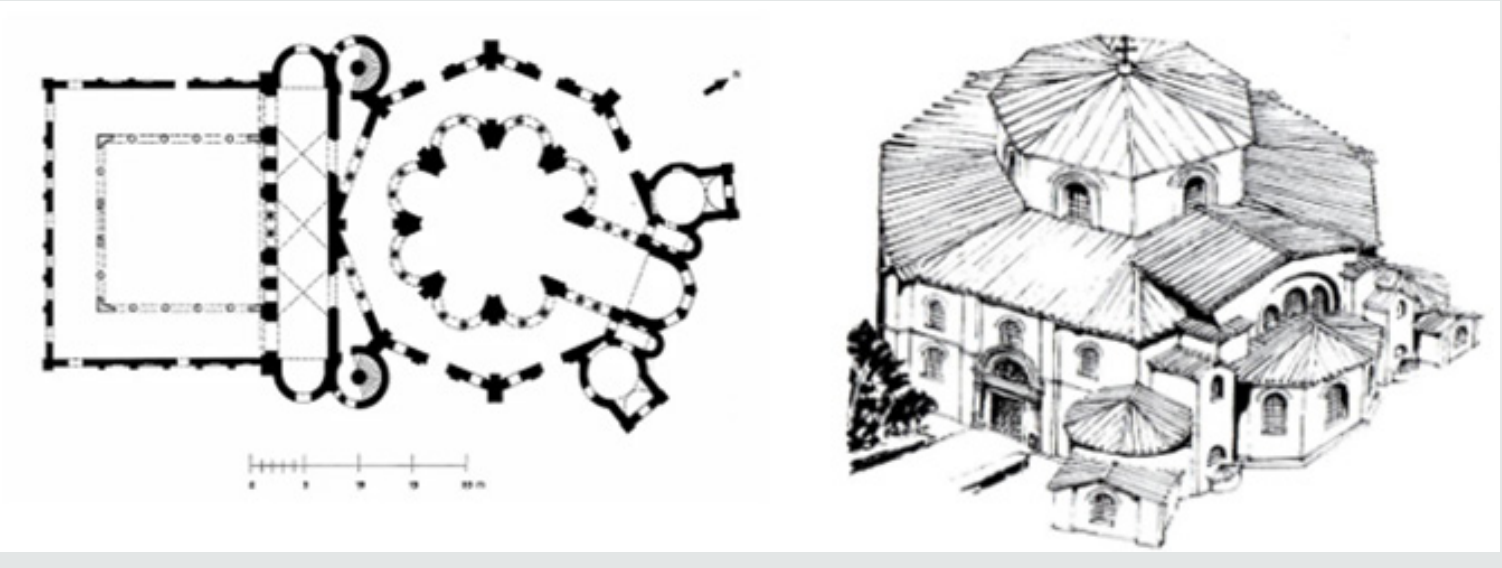

Figure 7: Plan;San Vitale, Ravenna;Byzantine architecture.

The ceiling of the church dome is characterized by a high height that allows a greater amount of light. The dome is 17 meters in height and 30 meters in height. It includes several distinct characteristics: its central layout, the structural arrangement of the central dome, the use of the surrounding islands, and how the structure, lighting, and decoration were integrated within the churchAgnellus [13].
The most famous example of Byzantine architecture, the hagia Sophia in Constantinople (532-37 A.D), was built on the site of a former chapel that was burned by riots and conquests at that time. The church is characterized by a unique structure in its architecture that combines central and longitudinal organization, which was planned and supervised by physicists and mathematicians, as it was the center of the Byzantine imperial celebrations John K [14]. 
Due to natural disasters such as seismic tremors, the dome of Hagia Sophia was destroyed and the structure was heavily damaged, and it was replaced by a new earthquake-resistant one by an Armenian engineer called Jaradat. In 1453 it was converted into an Islamic mosque, and in 1935 it was converted into a Turkish museum, the old minarets were replaced by the minarets that stand today and the addition of Islamic platforms and artVincenzo Ruggieri [15].

The general scheme is a round hall surrounded by a square, covered with a supported dome towards the long axis of the building with half domes over semicircular bridges. In this way, a 236-foot-and 98-foot-tall cathedral with domes is developed from an impressive central room. In the north and south, the dome is located on poles that open alongside lanesWilliam Richard Letha by, Harold Swainson [16].

Hagia Sophia consists of 100 construction pillars of white, green and porous marble, the floors and sidewalks were made of large stones mixed with lead, and the dome was completely covered with mosaics and contains 40 windows, and is located in the middle of the building, which requires a coherent and distinctive structural system to support loads and weightWilliam Richard Letha by, Harold Swainson [16].
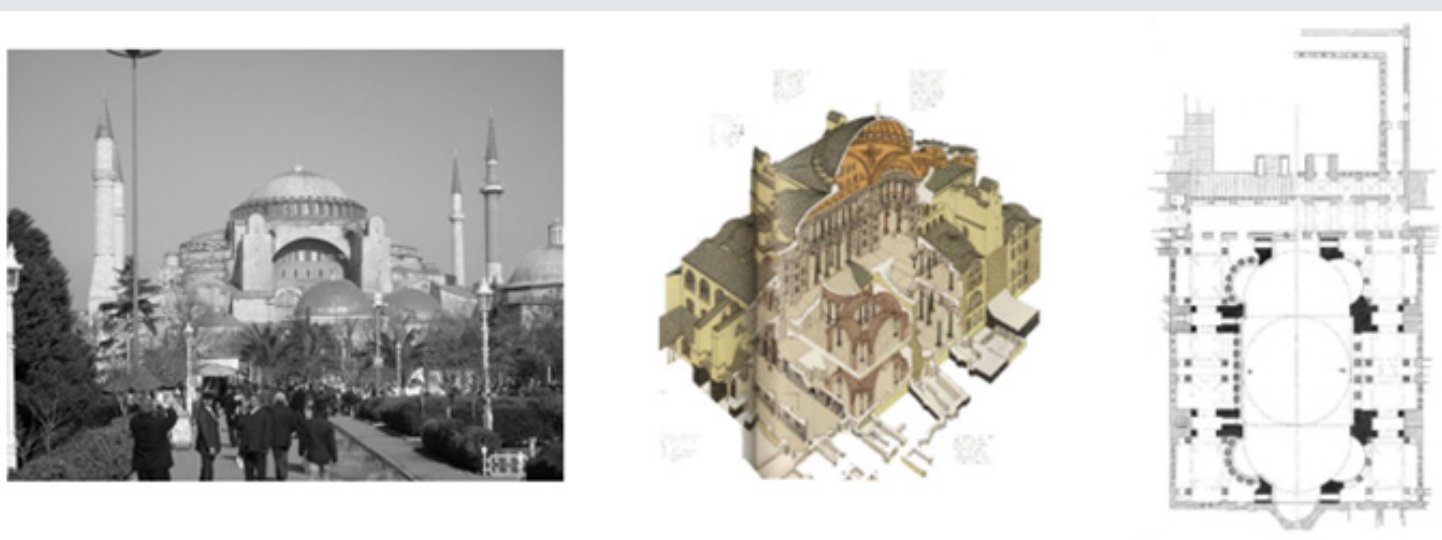

Figure 8: Plan; Perspective;the hagia Sophia;Byzantine architecture.

The dome is uniquely distinguished by being supported by four large piers and four corners, arranged in a square. The dome is 210 feet above the ground and is 110 feet in diameter. The dome is supported by hangers that were not previously used in building this structureWR Leatherby [17]. (Figure 8\& 9).
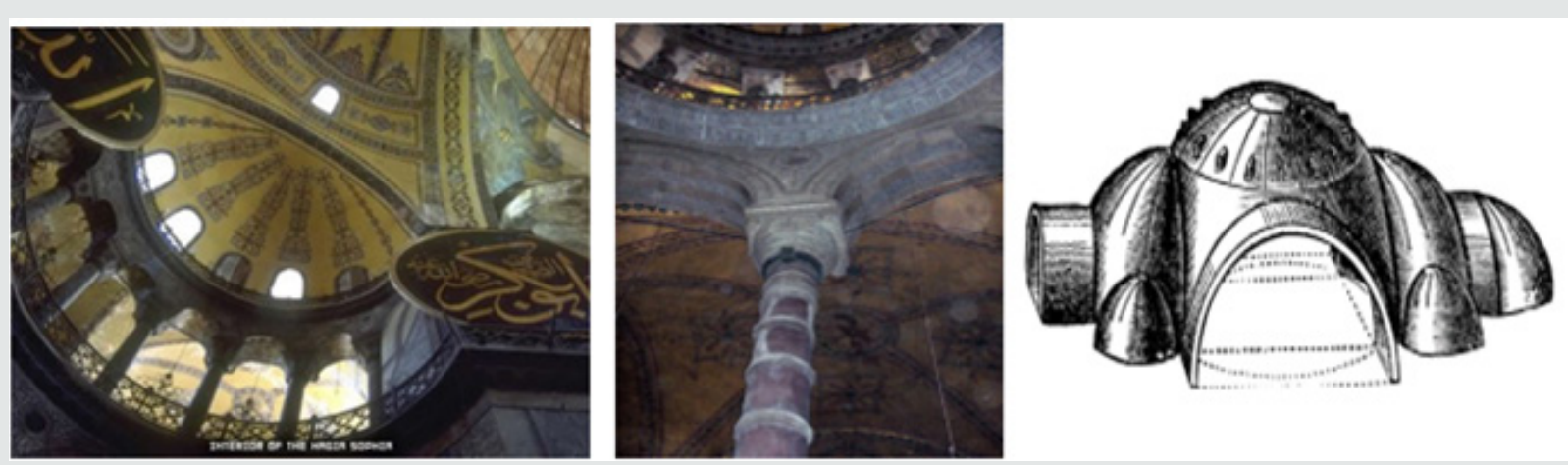

Figure 9: Perspective; the hagia Sophia;Byzantine architecture.

\section{Sassanid architecture 600 A.D (before the Arab conquest)}

Sassanid civilization began since the discovery of the ruins of Persepolis, approximately 2500 years ago, where it supported the use of local materials such as heavy clay, readily available in various places throughout the plateau. This in turn helped to develop more primitive building techniques, molded clay, strongly compressed when possible, allow it to dry. This technique has been used in Iran since ancient timesD. Huff [18].The Persian Empire was founded by King Ardashir I of Engineering, which flourished for more than 400 years (224-651 AD). It was characterized by the construction of castles such as Duchter Castle, Virgo Castle, and city construction such as the city of Ghor, an amazing circle with a diameter of 
1.2 miles and complexes of the capital Central ownership with a diameter of about 2000 feet. The architectural facades are characterized by rock inscriptionsMortezaDjamali, Alireza Askari Chaverdi [19] (Figure 10).
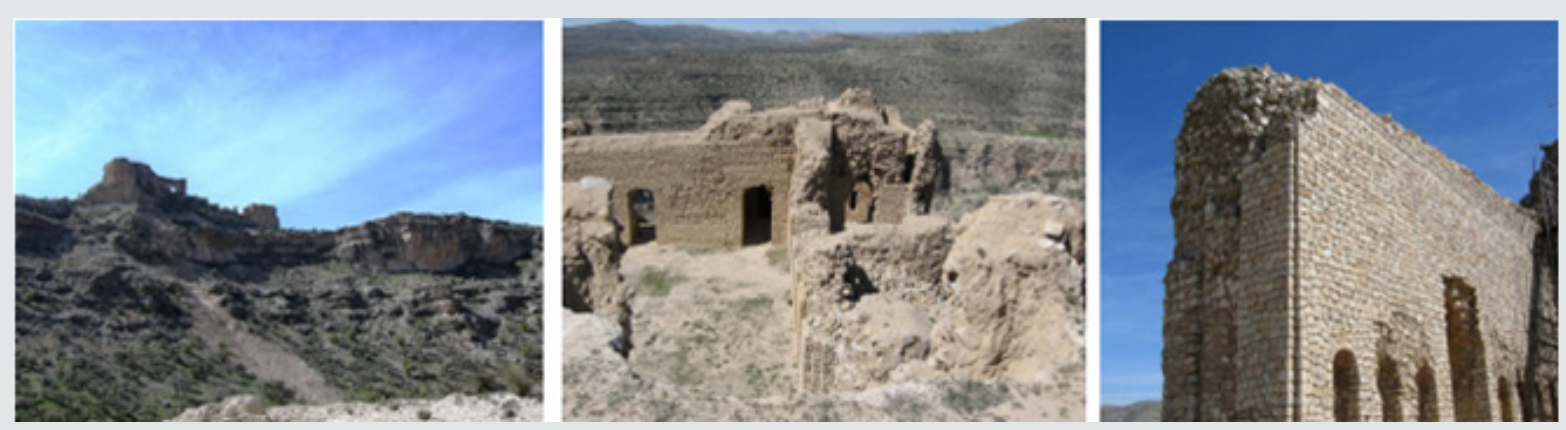

Figure 10: Perspective; the hagia Sophia;Sassanid architecture.

One of the most important archaeological buildings in the Sassanid civilization is the Ardeshir Palace, where the palace was characterized by domes built in particular and placed on rectangular bases, the Persians had no buildings marked by domes before the Ardeshir engineers discovered how. The palace is characterized by the presence of the domed balcony (Iwan), which enjoys a view of the lake. The surrounding of the dome worked to create spatial arrangements throughout the structureRahman Mehraby [20].
Persian architects and engineers were able to invent a technique that helps build huge domes over rectangular spaces called "squinch" as evidenced by the domes of the Ardeshir's Palace. Where it can be defined as an architectural device through which the upper or polygonal corners are formed to form a pillar of the dome (filling the corner with a small conical vault. It has an arc on its outer diagonal face and its head in the cornerMitra Karimi [21] (Figure 11).

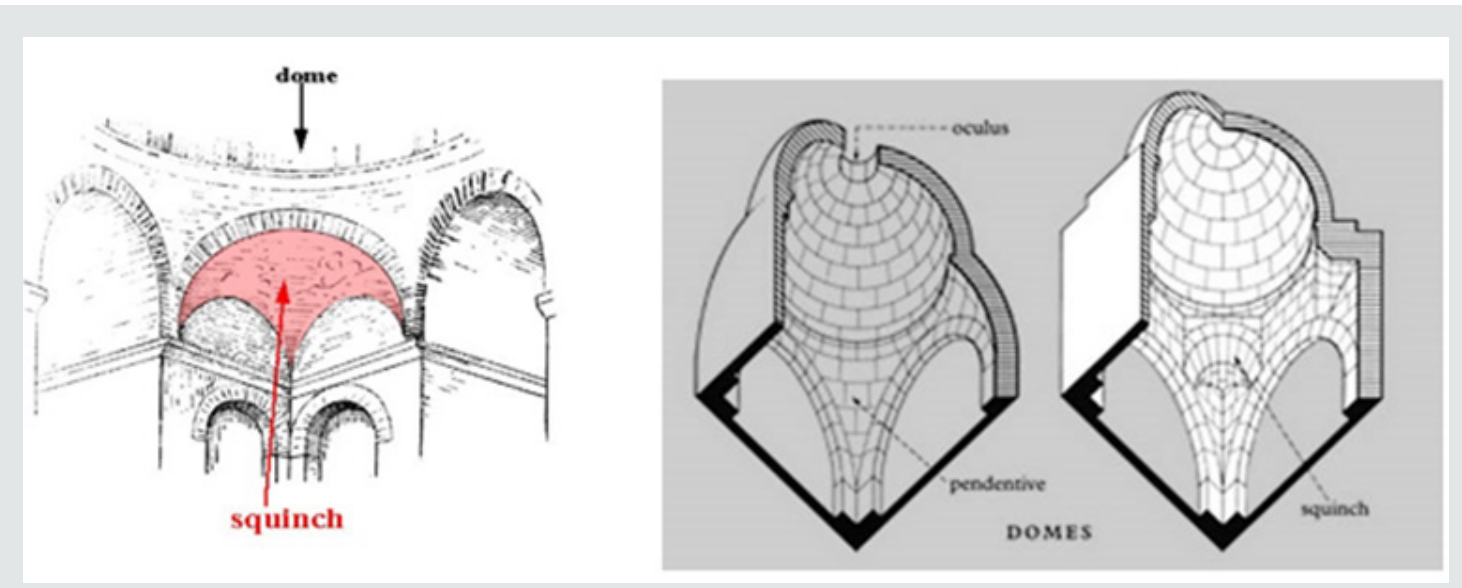

Figure 11: Technique, squinc; Sassanid architecture.

When tracing the Sassanid architecture, the distinctive historical monumental building must be mentioned Taq-i Kisra, which means Iwan of Khusraw, which is characterized by the famous Sassanian arch and Iwan arched hall, open on the side of the facade, with a height of about 37 meters and a length of 26 meters and a length of 50 meters, which is the largest basement built AbsolutelyPejmanAkbarzadeh[22].

The plan was organized symmetrically along the axis of the portal. On either side of the forty-eight-meter entry iwan, were large rectangular rooms served by corridors that wrapped around the iwan. a central hall covered with a vault identical to that of the iwan. the iwan vault was constructed without the use of any centering devices. A large paved court in front of the palace was used by Khusraw to address his subjectsEncyclopaedia Britannica [23].

IwanKesra is distinguished for having the largest domed area ever built, which was originally built of brick and covered with colored mosaic. As the way of construction is by moving the walls until they meet at one point. This type of construction, where no scaffolding was used to generate a well-rounded shape, produced a parabolic archPejmanAkbarzadeh[22](Figure 12). 

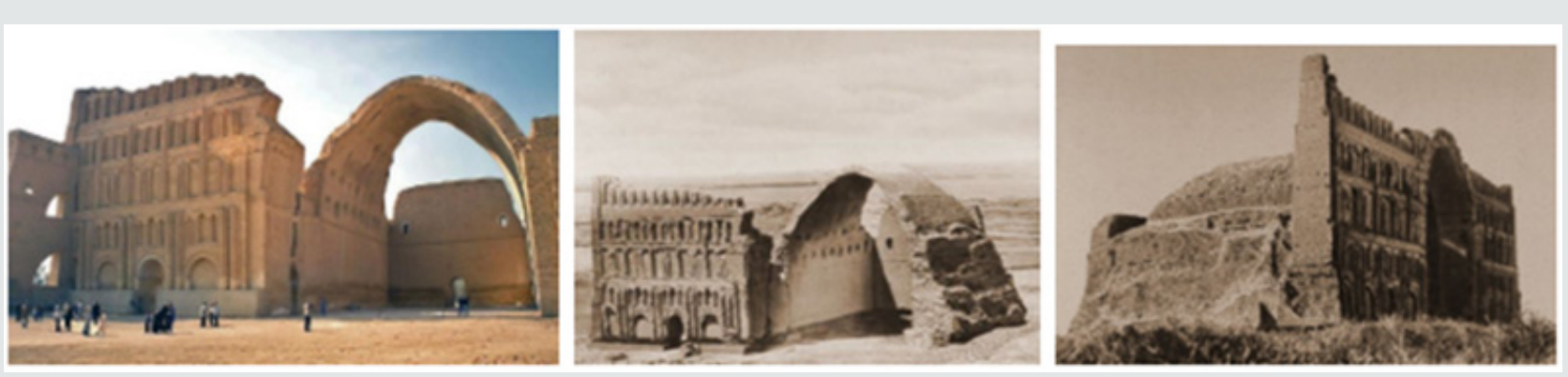

Figure 12: Taq-i Kisra;Sassanid architecture.

The unique characteristic of Sassanid architecture was its distinctive use of space. Buildings are characterized by the barrelvaulted iwans introduced in the Parthian period, but the Sassanid reached massive proportions, particularly at Ctesiphon. They solved the problem of constructing a circular dome on a square building by the squinch.

There are no passages or corridors in the Sassanid palaces. The apartments are numerous and en suite, opening one into another, without the intervention of passages. They conceived their building in terms of masses and surfaces; hence the use of massive walls of brick decorated with molded or carved stucco. The exterior ornamentation of the Sassanid from the ground to the cornice, while between them are a series of tall narrow doubly recessed arches.

\section{Romanesque Architecture (800-1200 A.D)}

The Roman churches witnessed a great development in terms of architecture, but slowly, due to climatic changes and other local conditions. King Charles the Great was the reason behind this great architectural revolution. Despite Rome's influence on the Byzantine style of architecture, it maintained a distinctive architectural style. Therefore, the design of the Roman churches was similar to the Byzantine churchesEncyclopaedia Britannica [24].
Roman architecture is characterized by encouraging the use of local building materials such as pebble, marble, terracotta, brick, prefabricated columns, and other features of ancient Roman buildings. They used the pattern of large openings in the northern facades to absorb the largest possible amount of light due to climatic conditions, and the pattern of small openings to reduce the sun's rays in the southern facadesValerie Spanswick [25].

The social organization had a major and effective role in the development of the Roman style of engineering, so the policy was that he wanted his land to build on him to advance to military service because of the wars of its time. The importance of the cities increased at that time, as the monastic system played a role in controlling the health situation in the rural areas before establishing hospitals in the citiesGert-Jan Burger [26].

After that, King Charlemagne, intending to recreate the Roman Empire as per its prototypes, decided that the architects agreed to follow the architectural style of S. Vitale in Ravenna which was a product of the Eastern Roman Romans, and S. Peter in Rome where the Carolingians adapted the Basilican plan to archaeological requirements Entering, Western business, the eastern tower (the transit tower), a type of cellar (leaning path around the eastern sanctuary) Matthias von Hellfeld [27] (Figure 13).

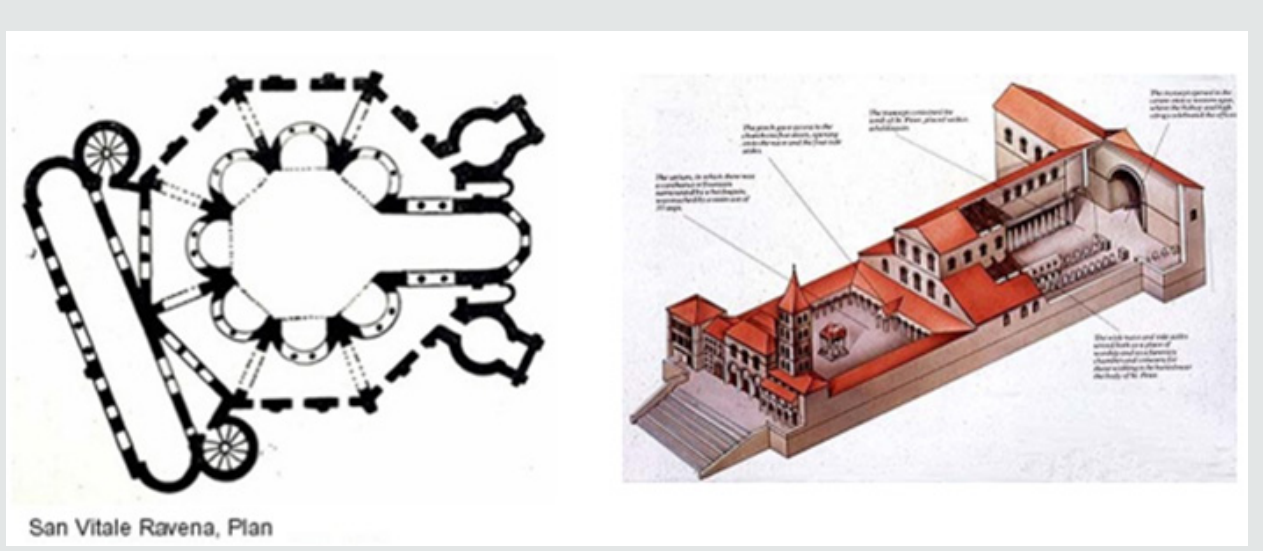

Figure 13: San Vitale, Ravenna A.D. 540-8,Basilica: S. Peter's Romebetween 326 and 333 A.D;Romanesque architecture. 
The most important characteristic of Roman architecture is the expression or emphasis on each structural section to produce uniform and easy-to-assemble structures, the development of pavement forms, an introduction to the triforium exhibition regular transit, the inclusion of wall corridors, elevators with radiant chapels, the development of new concepts in external masses, increased mastery For architectural carving, heavy stone construction with narrow openings, features such as round arch, thigh basement, barrel vault, vaulted rib development, jumping pole, central and western Spiers for churches and the replacement of columns, columns, decoration, and galleriesRishabh Shrivastav [28].

The Roman era is characterized by three types of buildings, which are churches, monasteries, and castles, where they were combined with characteristics, which are thick heavy walls that support the stone surfaces, the appearance of full ground, large and simple engineering blocks, the exterior reflects the internal structure and organization, the interior designs tend to be dark due to the huge walls Dictating small windows, increasing complexity in the basement to encompass large areas - casks, thighs, and ribs are usedAlida D [29].

The most prominent example of the Roman Church is the Church of S. Michael, Pavia, which follows the plan of the Latin cross. The plan of the Roman cathedral was subject to new developments during this period, and they added a new area called "the sanctuary" or "altar" and worked to increase the width and length of the passages to match the shape of the longitudinal cross Alberto Arecchi [30](Figure 14).

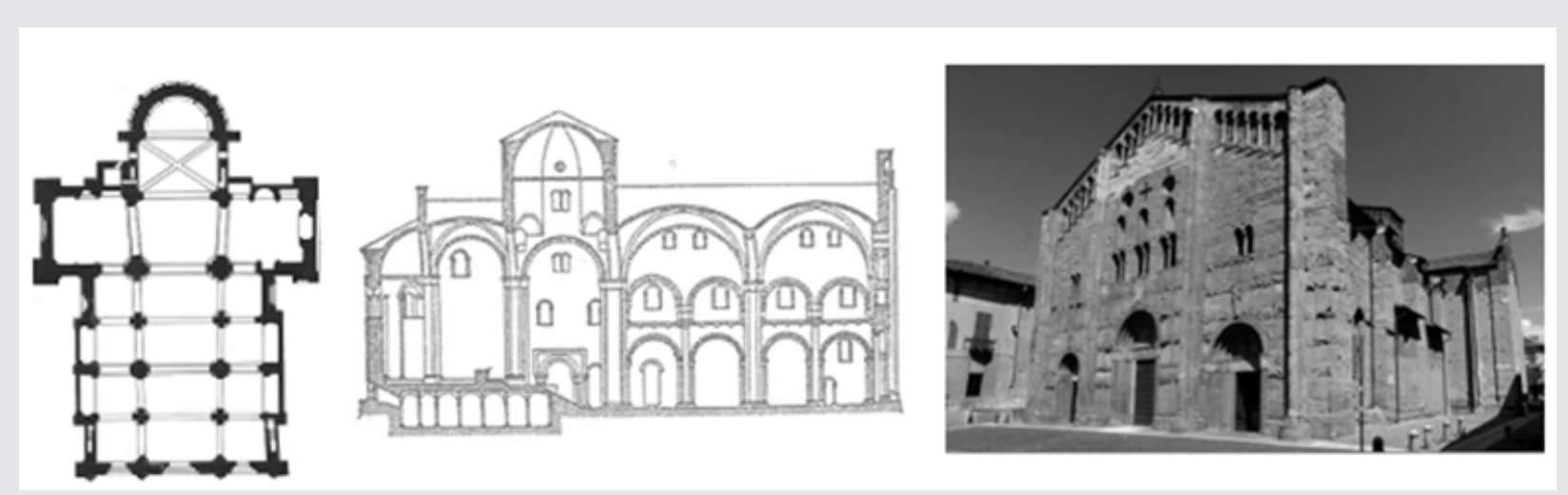

Figure 14: S. Michele, Pavia;Romanesque architecture.

Another historical example of the Roman Churches is the Church of the Apostle in Cologne, located on its sidewalks decorated with colored mosaic and on a vaulted crypt, where the saints or martyrs are buried, and pathways around the water channels are designed in them. Its structural structure includes towers, square, octagonal, or circular, which are prominent landmarks at the eastern and western ends and on crossing the nave and ferries, as in the Church of the Apostles, Cologne, and often rise to a large height in wellobserved stages, windows penetrated Marion Kutter [31](Figure 15).
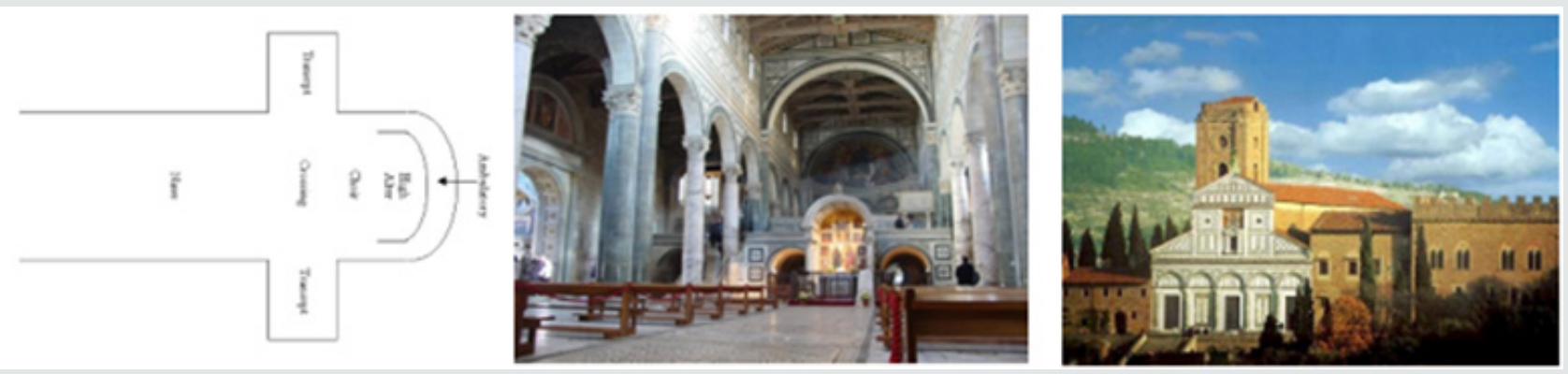

Figure 15: S. Apostle's Church at Cologne;Romanesque architecture.

Church walls are generally fishy with few and relatively small openings and rely on stone traditions (construction stone was often used in relatively small and irregular pieces, covered with thick mortars), and local masonry. The struts were used in the form of compact strips and attached to the top with strips of horizontal molds to reduce wall loads Isabelle Lomholt [32]. 
When tracing the Roman architecture, it is necessary to highlight the building of the Italian Leaning Tower of Pisa, where its style adheres to the type of basilica church outside. The focus was on the beauty and accuracy of the ornamental details - the use of ornamental arcades, and the use of marble to face walls. Originally, the builders' goal was not to construct the tilted tower, but because the site soil was not well examined, which led to the tilt of the tower automatically Keon Themes [33](Figure 16).
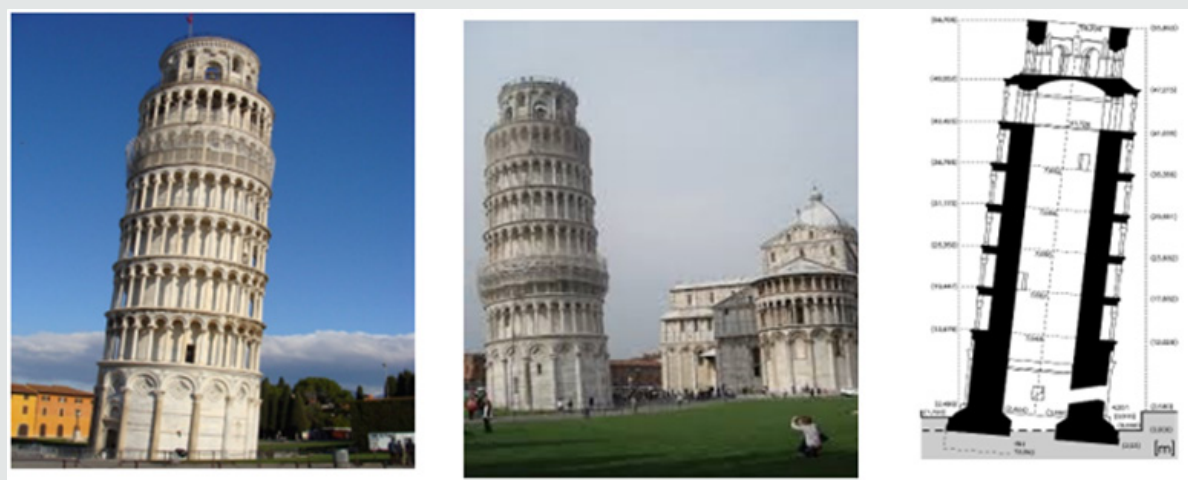

Figure 16: Tower of Pisa;Romanesque architecture..

\section{The Islamic Architecture (1200- 1516 A.D)}

When tracking Islamic architecture, an important question must be asked which is „Is the concept of Islamic architecture associated with structural elements such as domes, arches, or cellar?" It includes buildings that Muslims use for worship and secular buildings built in a Muslim-majority area. From an architectural aspect, the focus was on separating public and private spaces, as it included places with social gatherings in terms of separation. It is characterized by great diversity and the use of many concepts and different design methods Kelly Richman-Abdou [34].

Islamic architecture lived through the Byzantine and Sassanid eras at the beginning and continued to contemporary the Romanesque and Gothic eras. As the Byzantine architectural style continued for several years in various developing countries of the world, such as Jordan, and the Umayyad dynasty flourished at that time in its support for the geographical locations of the path of Muslim pilgrims Shervin Farridnejad [35].The Umayyads relied entirely on living in desert homes with the ability to adapt to the hot climate in summer and cold in winter. They built caravan stations, baths, fishing complexes, and palaces in the Jordanian desert. These palaces are collectively known as desert castles. Examples include the three-domed Umrah Palace bathroom with its magnificent wall walls and the huge Harran Palace Rabah Saoud [36].
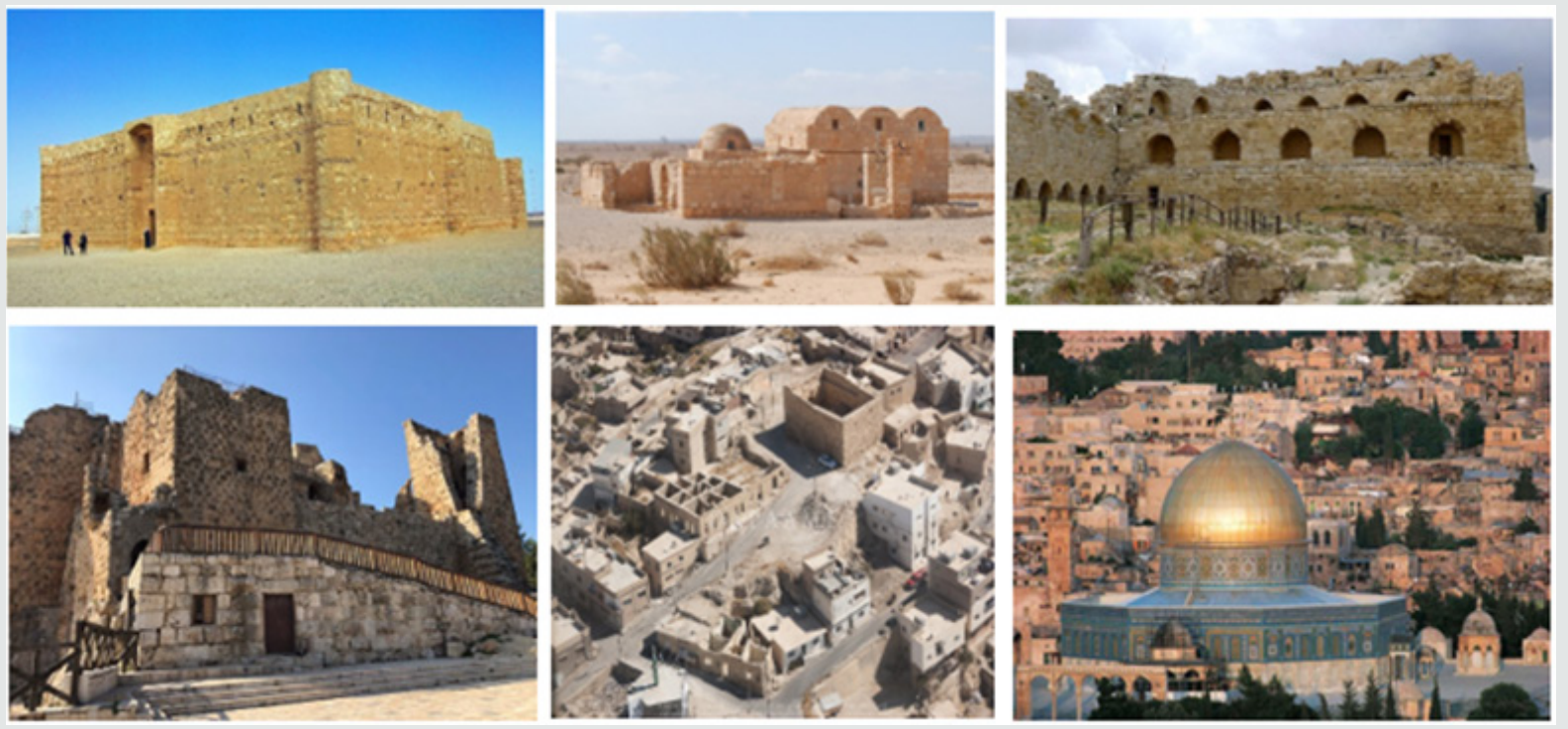

Figure 17: (a) Qasr Kharana, (b) Qusayr Amra, (c) Karak Castel, (d) Ajloun Castel, (e) TafilaCsatel, (f) Aqsa Mosque ;Islamic architecture. 
Castles and fortresses architecture flourished in Jordan due to the Crusades and the conquest of Jerusalem. The reason for building castles in Shobak and Karak was to protect the road from Jordan to Jerusalem. Where vernacular materials were used in the construction process (using the available materials). This, in turn, supported the importance of trade the economy and the discovery of architecture patterns in other countries and its reflection on the architecture and development of Jordan Mediterranean Heritage [37] Figure (18).
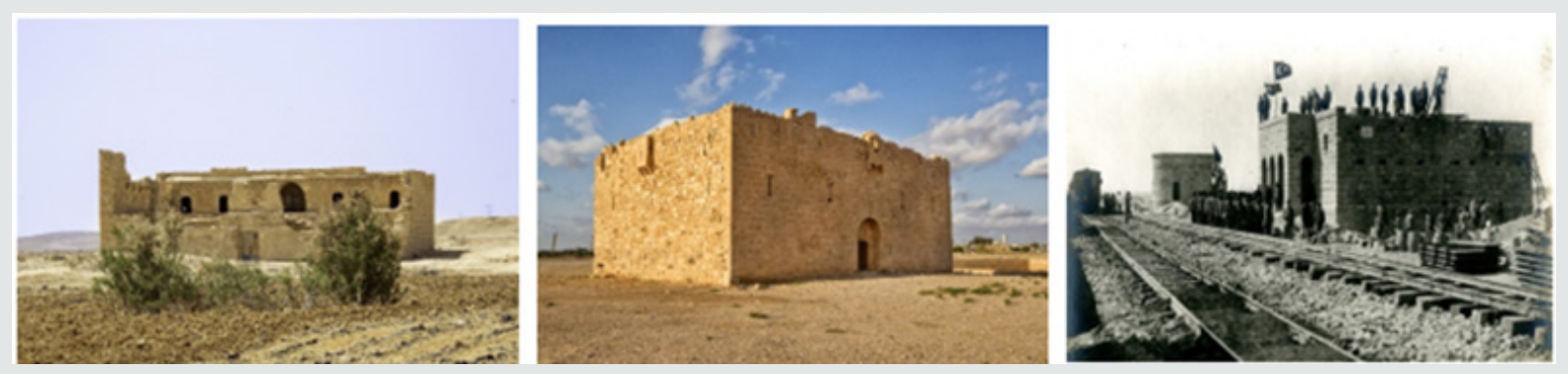

Figure 18: (a) Al-Ahsa Castle, (b) Qatrana castle, (c) Hejaz railway; Ottoman architecture.

\section{Ottoman Architecture(1516-1918 A.D)}

Ottoman architecture began with the Renaissance civilization, and it continued to contemplate the Baroque and Rococo civilizations, up to modern architecture. The Ottomans focused their attention on the Jordanian state due to its importance in supporting the pilgrimage route to Mecca. They built several forts such as Qasr al-Dabaa, Qasrtanah Qasr, and Al-Ahsa Castle J Freely [38].

The most important real achievement in the Ottoman era is the construction of the Hejaz railway that was designed to transport pilgrims to Mecca and provide them with food, water, and what they need. Which in turn supported the role of trade and mobility between countries, learn about their cultures and architectural styles, and learn from them to develop and improve the infrastructure of the architecture in JordanRamil M. Valeev, Alim M. Abidulin,Nailya I. Ayupova [39].

The source of the Ottoman architecture is derived from two main sources: the somewhat complicated development of new architectural forms and the other source is Christian art (the Byzantine tradition that was glorified in the construction of the Hagia Sophia). The Byzantine influence appears in features such as stone and brick used together or in the use of suspended dome construction. The distinguishing feature of Ottoman architecture is that it was derived from both Islamic and European artistic traditions, and was, therefore, part of both Rabah Saoud [40].

When tracing the Ottoman architecture, a large architect with an influential role - the largest Ottoman architect - Sinan Pasha, who designed the Selim Mosque in Edirne, and a large chain of churches and colleges who relied on giving each architectural element a hierarchical function in the overall composition, must be mentioned. It is attributed to the simplicity of composition, shapes, decorations, and even structural elements, and most of the buildings in this era depend on the presence of a majestic central dome. A type of series of descending domes, basements, and ascending stents directs the eye up and down from the outside Encyclopaedia Britannica [41] Figure (19).

\section{References}

1. Jackie Craven (2020) Architecture Timeline-Western Influences on Building Design. Thoughtco.

2. Linda Bleijenberg(2012) The origins of architecture according to Vitruvius. Origins of architecture

3. Patina Lee (2016) The History of Architecture in a Nutshell. Wide Wall.

4. Glasgow School of Art (2019)Roman Catholic Church Architecture in Britain, 1955 to 1975.

5. Allen Farber (2018) An Introduction to Early Christian Art and Architecture.

6. The Editors of Encyclopaedia Britannica (2017) New Saint Peter's Basilica. Encyclopædia Britannica.

7. Amy Raffel (2010) Jewish and Early Christian Art.

8. William R Caraher (2003) Church, Society, and the Sacred in Early Christian Greece.

9. Roger Stephen Sharp(2010) The Outside Image: A Comparative Study of External Architectural Display on Middle Byzantine Structures on The Black Sea Littoral.

10. Mark Cartwright (2018) Byzantine Architecture. Ancient History.

11. Mark J Johnson (2018) Planning and proportions in the domed octagonal churches of Late Antiquity.

12. J Arnott (John Arnott) Hamilton (1933) Byzantine architecture and decoration.

13. Agnellus (2005) The Book of Pontiffs of the Church of Ravenna.

14. John K (2013) The history of Byzantine architecture tripadvisor. Tripadvisor.

15. Vincenzo Ruggieri (1991)Byzantine Religious Architecture (582-867): Its History and Structural Elements.

16. William Richard Letha by, Harold Swainson (2012) The Church of Sancta Sophia, Constantinople: A Study of Byzantine Building. 
17. WR Leatherby (2009) The Church of Sancta Sophia Constantinople-A Study of Byzantine Building.

18. D Huff (2011) Architecture iii. Sasanian Period.

19. MortezaDjamali, Alireza Askari Chaverdi (2018) On the chronology and use of timber in the palaces andpalace-like structures of the Sasanian Empire in "Persis" (SW Iran).

20. Rahman Mehraby (2019) Palace of Ardeshir, the First Iranian Domed Structure.

21. Mitra Karimi (2008) Iran architecture in Sassanid era.

22. PejmanAkbarzadeh (2018) TAQ KASRA: Wonder of Architecture (Ancient Persia \& Mesopotamia).

23. Encyclopaedia Britannica (2017) ṬāqKisrā-ancient palace, Iraq.

24. Encyclopaedia Britannica (2017) Ottoman art. Encyclopædia Britannica.

25. Valerie Spanswick (2018) A beginner's guide to Romanesque architecture. Khan Academy.

26. Gert-Jan Burger (2002) Constructing Messapian Landscapes. BRILL.

27. Matthias von Hellfeld (dc) (2009) Charlemagne is crowned emperorDecember 25, 800. Made for Mind.

28. Rishabh Shrivastav (2016) What are the characteristics of Roman architecture? Quora.

29. Alida D (2016) Ancient Roman Architecture: Facts, Style \& Characteristics. Study.
30. Alberto Arecchi(2015) St. Michael's Basilica, Pavia. Academia.

31. Marion Kutter (2018) Cologne's Most Beautiful Romanesque Churches. Culture tripe.

32. Isabelle Lomholt (2019) Gesu Church Rome. e-architect.

33. Keon Themes (2020) Leaning Tower of Pisa: Facts \& Figures. The Arch Insider.

34. Kelly Richman-Abdou (2018)Dazzling Elements of Ancient Islamic Architecture We Still See Today. My Modern Met.

35. Shervin Farridnejad (2017) Sasanian Elements in Byzantine, Caucasian and Islamic Art and Culture.

36. Rabah Saoud (2004) Muslim Architecture under Ottoman Patronage (1326-1924). Foundation for science technology and civilation.

37. Mediterranean Heritage (2013) Desert Castles-Wealthy Umayyad Caliphs.

38. J Freely (2011) A History of Ottoman Architecture. Witpress.

39. Ramil M Valeev, Alim M Abidulin, Nailya I Ayupova (2017) The Project of Hejaz Railway Construction: A Historical and Historiographic Review. European Research Studies Journal.

40. Rabah Saoud (2002) Architecture under Umayyad Patronage (661-750). Muslim Heiratge.

41. Encyclopaedia Britannica (2017) Romanesque architecture. Encyclopædia Britannica.
This work is licensed under Creative Commons Attribution 4.0 License

To Submit Your Article Click Here: Submit Article

DOI: $10.32474 /$ TCEIA.2020.03.000175

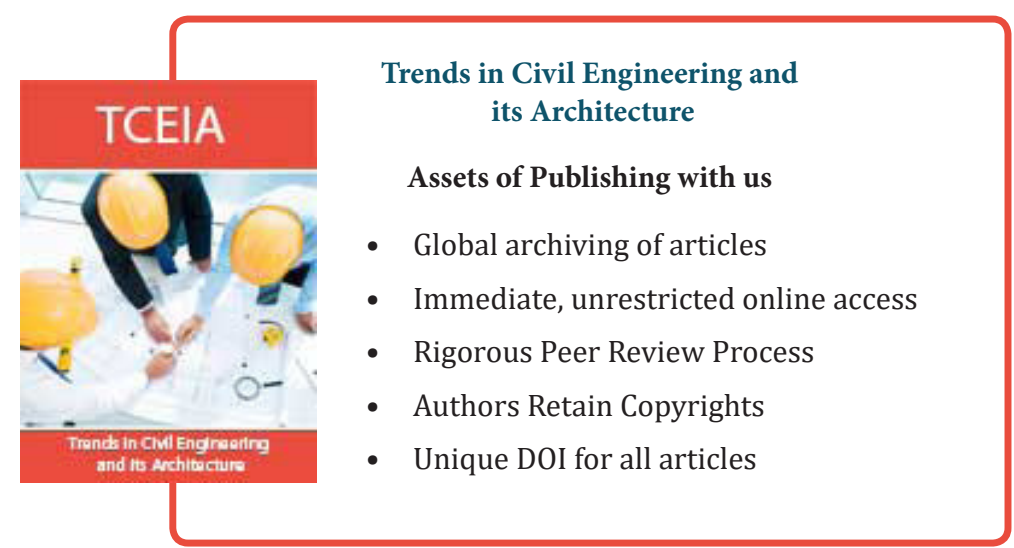

